\title{
OS NOVOS RUMOS DO DIREITO DA ELETRICIDADE
}

\author{
Maria AParecida de Almeida PinTo S. Fagundes
}

I - Introdução; II - Formato do setor elétrico no periodo anterior à reforma; III - As premissas do novo arranjo do setor; $I V-O$ novo direito da eletricidade; $V$ - Conclusão

\section{$I-$ Introdução}

A crise do Estado e a discussão acerca do seu redimensionamento estão na origem da profunda reestruturação pela qual passa hoje o setor elétrico brasileiro, requerendo um simétrico redesenho da legislação que o regula.

A estratégia de redução do papel do Estado para permitir-lhe dedicar-se a atividades em que sua presença se faz fundamental - basicamente, educação, saúde, segurança determinou a decisão de transferir-se a gestão de serviços públicos para a iniciativa privada, envolvendo, dentre outras providências, a outorga de concessões e a implementação de privatizações. Paralelamente, tem-se em mira, com a adoção dessa alternativa, obter-se um padrão mais elevado de eficiência na prestação desses serviços, dada a maior flexibilidade que caracteriza as atividades de um ente privado.

Essa opção resulta clara das palavras de Fernando Henrique Cardoso, no documento "Concessões de serviços públicos no Brasil", (SAE, 1995, pág. 9 e segs.), no seguinte sentido:

"A estratégia da reforma adotada no Brasil é a de buscar tornar o Estado mais efetivo em suas funções típicas e fortalecer o papel do setor privado na retomada do processo de desenvolvimento do País."

O setor elétrico não ficou imune às consequiências do esgotamento da capacidade financeira do Estado para investir em infra-estrutura. A partir do início da década de oitenta, os recursos para investimento foram escasseando, de tal sorte que o quadro existente era de obras paralisadas, caminhando em cadência muito lenta ou sequer iniciadas. 
$\mathrm{Na}$ raiz da crise desse setor, situa-se o grave estrangulamento econômico-financeiro das concessionárias estatais, que, há anos, detinham em suas mãos a prestação dos serviços de energia elétrica. Para tal situação, contribuíram, dentre outros fatores, a insuficiência tarifária, agravada pelos sucessivos planos governamentais de combate à inflação, que se valeram da rígida contenção tarifária como instrumento de política monetária, e as constrições trazidas por inúmeros (e, por vezes, superpostos) controles legais e administrativos, que lhes subtraíram agilidade. Configurou-se, pois, uma crise tanto de financiamento quanto institucional.

Ante à necessidade de expansão do setor, seja pelo cenário indicativo de deficit de energia, com risco de racionamentos, seja por sua relevância para a retomada do crescimento sustentado do País, tornou-se imprescindível convocar a iniciativa privada para assumir as atividades de financiamento e operação do mesmo, sob regulamento e fiscalização do Estado, tocando a este, ainda, responsabilizar-se pela formulação de políticas energéticas.

A sequiência ideal de desestatização do setor, a exemplo do que ocorreu em outros países que já passaram por essa experiência, deveria obedecer a três etapas. Na primeira delas, seria concebido o novo modelo; na segunda, elaborada a moldura legal e regulamentar mínima, capaz de viabilizar os objetivos almejados com a mudança; e, finalmente, na terceira, implantada a reforma.

Esse receituário não pôde ser observado no caso do setor elétrico brasileiro, tal era a urgência determinada pelas previsões sombrias de deficit de energia.

Assim é que, quando a modelagem da reestruturação foi concluída pelo consultor contratado pelo Governo, diversas medidas já haviam sido adotadas, tais como a criação do órgão regulador, o cancelamento de concessões para exploração de aproveitamentos energéticos, que envolviam realização de obras sequer iniciadas, a licitação destas e de outras concessões, a retomada de obras paralisadas, através de parcerias com o setor privado, a privatização de empresas distribuidoras de energia, a decisão de importar energia, e - o que é relevante para a matéria de que aqui se cuida - a edição da legislação indispensável à materialização dessas providências.

Tal atropelo, ditado pela quadro vislumbrado nos estudos empreendidos pelos planejadores energéticos, não permitiu que se estabelecesse, antecipadamente, um conjunto coerente de normas, afinadas com a nova feição que se pretendia emprestar ao setor.

A nova legislação foi e está sendo plasmada à medida em que se apresenta a necessidade de oferecer respaldo a cada uma das iniciativas acima referidas ou a outras tantas, ainda em fase de implementação. Essa circunstância tem determinado o surgimento de uma profusão de regras, pulverizadas em leis, decretos, regulamentos, muitas delas disciplinando uma mesma situação, outras alterando, logo a seguir, norma recente, com prejuízo de sua clareza e consistência.

\section{II - Formato do setor elétrico no período anterior à reforma}

Para que se compreenda o novo ordenamento jurídico do setor elétrico, que, em linhas gerais, delinearemos adiante, cabe sintetizar as premissas consideradas para 
a respectiva reestruturação, o que, por seu turno, pressupõe que se recordem, de forma a mais breve possível, suas características, no período anterior à reforma. Vale elucidar que, neste momento, em que se atravessa, justamente, a fase de transição, o modelo que vem sendo instaurado convive com traços do regime em substituição, com as dificuldades daí decorrentes.

Até meados do século passado, os investimentos no setor elétrico brasileiro eram, quase todos, encetados pela iniciativa privada, que dele acabou se retirando, em face da impossibilidade de praticar tarifas que, remunerando adequadamente o capital aplicado, the permitisse o equilibrio dos contratos de concessão e a realização dos investimentos necessários. O modelo privado foi, então, cedendo lugar ao estatal, ficando a prestação dos serviços de eletricidade, com raras exceções, a cargo de empresas que compunham a Administração Indireta, no âmbito federal e estadual.

Outro traço marcante do setor era a concentração das atividades de geração, distribuição, comercialização e transmissão, conforme o caso, em uma mesma empresa. Em outras palavras, as empresas eram organizadas de forma verticalizada (geradoras e distribuidoras eram também transmissoras e comercializadoras de energia; em alguns casos, uma mesma empresa concentrava, ainda, atividades de geração e distribuição de energia), produzindo uma sinergia que resultava em ganhos. Eram, portanto, proprietárias dos ativos necessários à consecução de cada uma dessas atividades.

De outra parte, o arcabouço do setor elétrico brasileiro, dadas as características naturais do País, cortado por rios de norte a sul, foi erigido a partir de um conjunto de usinas hidroelétricas, cujo insumo é a água, de que se dispõe em abundância.

As usinas térmicas funcionavam em regime complementar, em períodos de má hidrologia. Por essa razão, como não contavam com receita permanente, os gastos com o combustivel que utilizavam, quando chamadas a operar, eram rateados entre os integrantes do setor, através da chamada Conta de Consumo de Combustíveis, criada pela Lei $n^{\circ} 5.899$, de 05/07/93.

Cumpre realçar aqui a relevância para o abastecimento da energia proveniente de Itaipu, cuja aquisição se regula pela Lei acima referida, e da usina nuclear até então em funcionamento. (Angra I)

As usinas, interligadas por redes de transmissão, tinham sua operação coordenada por um colegiado, denominado Grupo Coordenador Para Operação Interligada $(G C O I)$, instituido pelo Decreto $\mathrm{n}^{\circ} 73.102$, de 07.11 .73 , em regulamento à mesma Lei $n^{\circ} 5.899$. Tão engenhosa quanto singular, já que não existe outra que se assemelhe no mundo, essa operação interligada propicia a racionalização do uso das unidades geradoras e das instalações de transmissão e, por consequiência, excepcional otimização energética do sistema.

Igualmente, o planejamento do setor esteve a cargo de um colegiado similar ao acima citado, chamado Grupo Coordenador de Planejamento Setorial (GCPS).

No que se refere a financiamento, o modelo tradicional, ora esgotado, envolvia o financiamento público, por intermédio de recursos fiscais e parafiscais, o autofinanciamento e o financiamento externo.

Outro aspecto relevante a ser destacado consiste no atendimento, pelas empresas, de mercados cativos, distribuídos por áreas. Assim, determinada geradora provia 
energia às distribuidoras existentes na sua área de atuação, que, por sua vez, forneciam energia a um conjunto de consumidores, residenciais e industriais, obrigados a valer-se dos serviços por ela prestados, salvo as hipóteses de auto- produção, já então previstas na legislação (Código de Águas, baixado pelo Decreto ${ }^{\circ}{ }^{2} 2.643$, de 10.07.34 regulamentado pelo Decreto $\mathrm{n}^{\circ} 41.019$, de 26.02.57).

Mais recentemente, de acordo com as regras introduzidas pela Lei $\mathrm{n}^{\circ} 8.631$, de 04.03.93, regulamentada pelo Decreto $\mathrm{n}^{\circ} \mathbf{7 7 4}$, de 18.03.93, as relações contratuais entre supridores e supridos passaram a ser objeto de contratos de suprimento de energia, celebrados por períodos de 10 (dez) anos, revisando-se, a cada ano, por aditamento, os montantes de energia e demanda neles contemplados.

Finalmente, mas não menos importante, apesar da disciplina tarifária introduzida pela supracitada Lei ${ }^{\circ} 8.631$, facultando aos concessionários a proposição do nível de tarifa necessário à cobertura dos respectivos custos, em substituição à política de equalização tarifária, até então vigente; apesar, pois, repetimos, do previsto nessa Lei, desde a edição do Plano Real (Lei ${ }^{\circ} 9.069$, art. 70) os reajustes e revisões das tarifas ficaram sob controle do Governo, significando, na prática, tarifas regulamentadas.

\section{III - As premissas do novo arranjo do setor}

As mudanças propostas para o setor elétrico brasileiro guardam muita semelhança com experiências nessa área, levadas a cabo por outros países, a partir da promulgação, em 1978, nos Estados Unidos, do Public Utilities Regulatory Policy $A c t$, do qual se extraem os princípios gerais que dão os contornos do novo arranjo do regime dos serviços elétricos.

A redefinição desse setor, nos diferentes países, teve como principal alvo a organização de um mercado competitivo, seja através da re-regulamentação (deregulation), como se deu nos Estados Unidos, onde já era predominantemente privado, seja mediante a adoção de estratégias de reestruturação, abrangendo privatizações, onde era nacionalizado e centralizado.

Nessa esteira, a reformulação do setor elétrico brasileiro tem como eixo central a idéia da criação de um mercado de energia, no âmbito do qual movimentar-se-ão múltiplos agentes: diversos geradores, distribuidores, transmissores, comercializadores, exportadores e importadores de energia e consumidores livres para optar pelo respectivo fornecedor.

No novo ambiente, no qual se reserva papel de maior destaque para os agentes privados, por força de outorga de concessões, autorizações e de privatizações, os preços de venda de energia serão negociados livremente. Aposta-se na competição como fator indutor de ganhos em eficiência e de redução de tarifas, embora esse objetivo não fique expresso nos relatórios produzidos pelo consultor responsável pela montagem do modelo.

Balizou-se, destarte, a reforma na implementação das seguintes condições básicas: (a) criação de um órgão regulador independente; (b) consideração da geração de energia elétrica como atividade industrial e não como serviço público; (c) plane- 
jamento, programação e despacho das unidades geradoras neutros, demandando a criação de uma entidade que os executasse, denominada Operador Nacional do Sistema Elétrico (ONS), que substituiria o já citado GCOI; (d) garantia de livre acesso de todos os agentes do mercado ao sistema de transmissão; (e) segregação das atividades de geração e transmissão; (f) estabelecimento de número adequado de geradores, distribuidores e comercializadores, de portes semelhantes, de sorte a ensejar o surgimento de um mercado de energia, chamado Mercado Atacadista de Energia Elétrica - MAE, no âmbito do qual se realizarão operações a termo e de curto prazo (mercado spot); e (g) criação de um direito progressivo dos consumidores, a partir dos que demandam uma carga maior de energia, de escolherem os seus supridores de energia, negociando as condições, inclusive preço, do respectivo abastecimento.

\section{IV - O novo direito da eletricidade}

\section{$I$ - O ordenamento legal anterior à reforma}

A partir do acima exposto, tem-se a dimensão da profundidade e complexidade da reestruturação do setor elétrico brasileiro, ora em curso, passando-se do paradigma estatal para o privado, o que, por óbvio, requereu, como já assinalado, a concepção de um aparato legal que a suportasse.

Tal arcabouço se encontra em plena fase de construção. À medida que ele vai sendo moldado, começam a aflorar questionamentos jurídicos, que já se plantam como tema de discussões doutrinárias.

Abordamos, em seguida, os principais marcos legais e regulamentares da mudança. Muitos deles apresentam conteúdo bastante técnico, mas nos limitaremos a destacar seus reflexos mais significativos, do ponto de vista jurídico.

Durante décadas, as atividades de geração, distribuição e transmissão de energia elétrica estiveram sujeitas, no plano infra-constitucional, à disciplina do já citado Código de Águas, sua primeira regulação sistemática.

Ao longo dos anos, as disposições dele constantes bem como de seu regulamento foram detalhadas por inúmeros decretos e portarias. Nesse meio tempo, surgiram algumas leis, voltadas para a disciplina de situações específicas, a exemplo da Lei $\mathrm{n}^{\circ} 5.655$, de 20.05.71, que estabeleceu normas relativas à remuneração dos investimentos dos concessionários e à quota de reversão (RGR), a ser por estes paga ao Poder Concedente, ou da Lei ${ }^{\circ} 5.899$, de 05.07.73, já acima referida, que dispôs sobre a aquisição dos serviços de eletricidade da Usina de Itaipu ou, ainda, do Decreto-lei $n^{\circ} 2.432$, de 17.05 .88 , que instituiu a Reserva Nacional de Compensação de Remuneração - RENCOR, criou a tarifa de transporte da potência de Itaipu e dispôs sobre matérias outras.

Quando sobreveio a crise dos anos 80 , o setor elétrico adotava, portanto, um modelo tarifário, respaldado pelo Código de Águas e por essa legislação esparsa, assentado no regime do "serviço pelo custo", mas estruturado dentro de uma visão de repartição de ônus e bônus dentro do sistema. 
De um lado, a supracitada Lei ${ }^{\circ} 5.655$ garantia ao concessionário - decerto uma tentativa de observância do princípio de garantia do equilíbrio econômico-financeiro das concessões - um patamar mínimo de remuneração, variando de $10 \%$ a $12 \%$, simbolizado em um artifício contábil, representado pela Conta de Resultados a Compensar - CRC, onde se registravam os déficits ou excessos de remuneração.

De outra parte, contudo, em 1974, a mencionada Lei é alterada, através do Decreto-lei $\mathrm{n}^{\circ} 1.383$, introduzindo-se um mecanismo de equalização tarifária, cujos custos passam a ser suportados por uma espécie de câmara de compensação, transferindo-se recursos de uma empresa para outra, como subsídio às regiões menos desenvolvidas, por via da chamada Reserva Global de Garantia. Essa política retirou das empresas qualquer autonomia empresarial e contribuiu para comprometer a sua estrutura financeira.

\section{2 - Antecedentes legais: base das novas normas especificas para o setor}

\section{a) Lei $n^{\circ} 8.631 / 93$}

Identifica-se na edição da Lei ${ }^{\circ} 8.631$, de 04.03.93, regulamentada pelo Decreto $\mathrm{n}^{\circ} 774$, de 18 de março do mesmo ano, o primeiro esboço de reação à crise em que estava mergulhada o setor. Por essa razão, vale referi-la antes de outros diplomas que a precederam.

Através dela, elimina-se a equalização tarifária e a remuneração garantida, extinguindo-se a RENCOR e a CRC. Comete-se, agora, em uma inversão de competência, a cada concessionário a tarefa de propor o respectivo nível tarifário, de sorte a cobrir os custos do serviço e a remuneração do investimento. Ao Poder Concedente a nova sistemática legal defere o controle da legalidade da proposta do concessionária, mediante homologação da proposta ou do reajuste tarifários, valendo a ausência de manifestação, no prazo de 15 (quinze) dias, como concordância.

Apesar da nova ordem de competência, imposta por disposições legais, o então DNAEE, através de diversos atos, mostrou-se refratário a exercer conduta meramente homologatória. Posteriormente, a Lei $n^{\circ}$ 9.069/95, que implantou o Plano Real, deitou uma pá de cal no modelo, quando, em seu art. $70, \S 2^{\circ}$, alocou à área econômica a administração tarifária.

Sobreleva notar que a prefalada Lei teve, outrossim, como um de seus objetivos, trazer ordem ao setor, marcado por forte inadimplência de algumas das empresas que o compunham, tornando obrigatória a assinatura de contratos de suprimento, que passaram a contemplar, inclusive, mecanismos de garantia de pagamentos.

Já antecipando-se às profundas modificações que estavam por acontecer, a Lei em questão previu, ainda, a criação de Conselhos de Consumidores pelos concessionários de distribuição, no âmbito da sua área de concessão.

\section{b) Constituição Federal de 1988, Emenda Constitucional $n^{\circ} 6$ e Emenda} Constitucional $n^{\circ} 19$

Mas, como vimos, a reforma do setor elétrico está intimamente ligada ao imperativo de redimensionamento do Estado. A diminuição do papel deste último, 
nesse setor, envolve iniciativas variadas, tais como privatizações, estabelecimento de parcerias e, sobretudo, a descentralização de gestão, mediante a utilização de técnicas como a de outorga de concessões e permissões.

Sob essa ótica, a Constituição Federal de 1988, mercê da regra inscrita em seu art. 175, representa um divisor de águas, eis que introduz a matriz do regime de concessões de serviço público, que propiciará a prefalada descentralização.

De fato, consoante referido permissivo, a prestação dos serviços públicos incumbe ao Poder Público, que poderá executá-los diretamente ou sob regime de concessão ou permissão, impondo-se, neste caso, a realização de prévia licitação. Acrescente-se que, na forma do respectivo parágrafo único, ficou subordinada à edição de lei futura a disciplina de aspectos fundamentais das concessões, a saber: o regime das empresas concessionárias e permissionárias; o caráter do contrato de concessão ou permissão, as condições para sua prorrogação, assim como de caducidade, fiscalização e rescisão; os direitos dos usuários; a política tarifária; a obrigação de manter serviço adequado.

Cabe aqui mencionar que, ao estabelecer no art. $37, \S 3^{\circ}$, que

"as reclamações relativas à prestação de serviços públicos serão disciplinadas em lei",

a Carta Magna já dava ênfase ao direito do usuário de receber serviço adequado, conferindo-lhe o direito de protestar caso isto não ocorra.

A redação desse preceito foi bastante ampliada com o advento da Emenda Constitucional $n^{\circ} 19$, que, a propósito, assim dispôs:

" $\S 3^{\circ} \mathrm{A}$ lei disciplinará as formas de participação do usuário na administração pública direta e indireta, regulando especialmente:

I - as reclamações relativas à prestação dos serviços públicos em geral, asseguradas a manutenção de serviços de atendimento ao usuário e a avaliação periódica, externa e interna, da qualidade dos serviços;"

Nas palavras do eminente Ministro do Superior Tribunal da Justiça, Carlos Alberto Direito, em artigo intitulado "Reforma Administrativa: a Emenda $\mathrm{n}^{\circ}$ 19/1998" (RDA, vol. 213, pág. 135),

“... este comando constitucional pode ter um efeito tão poderoso quanto o Código de Defesa do Consumidor. Na verdade, trata-se de elaborar uma Lei de Defesa do Usuário dos Serviços Públicos. Como todos sabemos, o Código de Defesa do Consumidor alcançou uma tal dimensão que hoje, na lição de mestres como Ruy Rosado de Aguiar e Sérgio Cavalieri, a sua presença social é mais importante do que a do próprio Código Civil."

Ainda em sede de matéria constitucional, pode-se destacar a Emenda Constitucional $n^{\circ} 6$, de 15.08.95, que, ao alterar o art. 176, $\S 1^{\circ}$, da Carta Magna, passou a admitir como passível de tornar-se titular de concessão ou autorização para aprovei- 
tamento de potencial de energia hidráulica a empresa constituída sob as leis brasileiras e que tenha a sua sede e administração no País, em lugar da anteriormente mencionada empresa brasileira de capital nacional. Na prática, eliminaram-se, com essa modificação, as restrições a que investidores estrangeiros construíssem e explorassem usinas hidrelétricas.

\section{c) Lei $n^{\circ} 8.031 / 90$ e Lei $n^{\circ} 9.491 / 97$}

Por uma questão de cronologia, cabe aqui mencionar o importante papel desempenhado pela Lei ${ }^{\circ}$ 8.031, de 12.04.90, que, no nível federal, lançou as bases da política de privatizações.

Essa Lei foi revogada pela Lei $n^{\circ} 9.491$, de 09.09.97, que consolidou modificações nela introduzidas por diversas Medidas Provisórias. Algumas dessas alterações foram julgadas relevantes para viabilizar a desestatização da prestação dos serviços públicos, e, por conseguinte, dos serviços de energia. Dentre elas, mencionem-se as normas insculpidas nos arts. $2^{\circ}, \S 1^{\circ}$, e $4^{\circ}$. das quais se infere a consideração de concessões e permissões como modalidade de desestatização. Supõe-se que, com esta providência, teve-se por objetivo prover autorização legislativa de caráter genérico para a respectiva outorga, o que, a rigor, seria desnecessário, já que os contratos celebrados nessa seara estariam submetidos ao poder de direção da máquina administrativa, conferido ao administrador, e sujeitos à legislação que lhes é própria.

Outra modificação a ser realçada, contemplada no art. $7^{\circ}$, consiste na garantia de que a desestatização dos serviços públicos envolverá a delegação da concessão ou permissão, objeto da exploração.

Cabe mencionar que, com base na Lei $\mathrm{n}^{\circ} 8.031$, já foram privatizadas várias empresas do setor, no âmbito federal e estadual. No plano federal, a Espírito Santo Centrais Elétricas S/A - ESCELSA e a Light Serviços de Eletricidade S/A foram incluídas no Plano Nacional de Desestatização - PND, por força do Decreto $\mathrm{n}^{\circ}$ 572, de 22.06.92, enquanto as empresas do grupo ELETROBRÁS figuram no Plano, a partir do advento do Decreto $\mathrm{n}^{\circ} 1.503$, de 25.05.95.

\section{d) Lei $n^{\circ} 8.987 / 95$}

Feita essa digressão, voltamos aqui ao art. 175 da Carta Constitucional, que alude a uma futura lei regulamentadora do quanto nele se dispôs.

Justamente para dar cumprimento à previsão desse artigo da Constituição é que veio a ser editada a Lei $n^{\circ} 8.987$, de 13.02.95, enfeixando as regras básicas relativas às concessões e permissões de serviço público e, por esse motivo, chamada Lei Geral de Concessões.

A Lei em tela se aplica à concessão de serviços de energia elétrica, visto que, na forma do art. 2l, inciso XII, letra b, da Constituição Federal, consideram-se serviços privativos da União, a serem por ela explorados diretamente ou mediante autorização, concessão ou permissão 
"os serviços e instalações de energia elétrica e o aproveitamento energético dos cursos de água, em articulação com os Estados onde se situam os potenciais hidroenergéticos".

A Lei $\mathrm{n}^{\circ} 8.987$ encerra normas destinadas à disciplina das licitações e contratos de concessão e permissão de serviço público, dos encargos do Poder Concedente e do concessionário, da intervenção e da extinção da concessão. Dentre essa regras, algumas apresentam especial interesse para o assunto que aqui se aborda.

Assim, por exemplo, merece relevo o tratamento dispensado pelo diploma legal em apreço à política tarifária, até porque nela se encontra a chave da conjugação harmoniosa da satisfação do interesse público e da obtenção de lucros - finalidade precípua da empresa privada - a ser alcançada por intermédio da concessão.

Combinando-se o disposto nos arts. $9^{\circ}$ e 15 da Lei em comento, o valor da tarifa será determinado na licitação, observados os critérios de julgamento de menor valor da tarifa ou de maior oferta pela outorga da concessão.

Demais disso, a Lei prevê que o edital contenha as regras de reajuste e revisão das tarifas, com vistas à respectiva preservação e, portanto, â manutenção do equilíbrio econômico-financeiro do contrato.

No setor elétrico, ditas regras foram estabelecidas, por exemplo, nos contratos de concessão, constantes do edital de privatização da ESCELSA e da LIGHT.

Segundo informa Armando Castelar Pinheiro (artigo intitulado "O Setor Privado na Infra-estrutura Brasileira", publicado na "Revista do BNDES", n 5 , págs. 87 a 103 ), se no contrato celebrado com a primeira das empresas acima citadas a cláusula de revisão foi redigida em termos não suficientemente claros (talvez, pensamos, em virtude do seu pioneirismo), naquele ajustado com a LIGHT já se verifica algum avanço, com a introdução de mecanismos tais que, após um dado número de anos, procede-se à revisão da tarifa, de sorte a permitir, conforme o caso, tanto o re-equilíbrio em favor do concessionário, quanto o repasse dos ganhos de produtividade para os consumidores. Ainda relacionada à questão tarifária, a Lei traz, em seu art. 11, inovação interessante, ao autorizar que o Poder Concedente, atendendo às peculiaridades de cada serviço, preveja, no edital, em favor do concessionário, a possibilidade de outras fontes provenientes de receitas alternativas, complementares, acessórias ou de projetos associados, com ou sem exclusividade, para viabilizar a modicidade da tarifa.

Para que se componha dessa forma a remuneração do concessionário, infere-se dos princípios fundamentais que norteiam as licitações que as atividades adicionais estejam contempladas no edital. Assim se passou na prefalada privatização da ESCELSA, cujo edital admitiu a possibilidade de exploração de serviços de dados e de telecomunicações, mediante utilização da rede de distribuição de energia elétrica.

Considerando, todavia, que, em geral, as concessões se estendem por prazo bastante longo, afigura-se impossível, em determinadas hipóteses, prever todas as receitas alternativas que poderão contribuir para a modicidade das tarifas no curso desse extenso período. Caberá, portanto, à agência reguladora decidir, em face do interesse público envolvido, se o concessionário poderá ou não auferir outras receitas alternativas e como isso repercutirá no contrato de concessão. 
A esse propósito, pode-se trazer, como exemplo, a solução encontrada pela Agência Nacional de Energia Elétrica - ANEEL, ao disciplinar a utilização da rede de transmissão das empresas do sistema ELETROBRÁS no negócio de telecomunicações.

Nessa hipótese, aquela entidade definiu, através da Resolução $\mathrm{n}^{\circ} 239$, de 04.08.99, que apenas parte da receita auferida com dita utilização fosse considerada para efeito de modicidade tarifária, ficando o restante disponível para investimentos, no serviço público, por parte das empresas proprietárias dos ativos de transmissão.

Cumpre, outrossim, mencionar o enfoque especial que a Lei cuidou de conferir, no respectivo art. $6^{\circ}$, à prestação do serviço adequado, abrangendo as condições de regularidade, continuidade, eficiência, segurança, generalidade e cortesia.

Vale ressaltar que, na forma do $\S 3^{\circ}$ desse artigo, admite-se, como exceção à condição de continuidade, a suspensão dos serviços por inadimplemento do usuário.

A incidência desse permissivo, na hipótese de prestação de serviços de distribuição de energia elétrica, foi, durante algum tempo, objeto de controvérsia, à vista do disposto no art. 22 da Lei ${ }^{\circ}$ 8.078/90 (Código de Defesa do Consumidor), cujos dizeres são os seguintes:

"Os órgãos públicos, por si ou suas concessionárias, permissionárias ou sob qualquer outra forma de empreendimento, são obrigados a fornecer serviços adequados, eficientes, seguros e, quanto aos essenciais, contínuos."

Contudo, no Parecer CONJUR/MME, publicado no "Diário Oficial", de 8.07.97, a Consultoria Jurídica do Ministério de Minas e Energia, respaldada em significativa jurisprudência, emitiu opinamento no sentido de que, guardadas as cautelas devidas, relativas à prévia comunicação, a falta de pagamento da tarifa, por parte do usuário, enseja a interrupção do fornecimento de energia elétrica. Em auxílio de sua tese, argumenta que, sendo o serviço custeado através da tarifa, tal inadimplemento compromete o equilíbrio do contrato de concessão e, consequientemente, a própria continuidade do serviço, em desfavor dos demais consumidores.

A matéria hoje já está disciplinada na Resolução ${ }^{\circ} 456$, de 29.11.2000, da ANEEL, que, em seu art. 91, prevê as condições sob as quais se pode dar tal suspensão do fornecimento de energia.

Arrolam-se, no art. $7^{\circ}$, sem prejuízo do previsto na lei específica (a supracitada Lei $\mathrm{n}^{\circ} 8.078 / 90$ ), os direitos e obrigações dos usuários, sendo o primeiro dos direitos garantido, como já vimos, pela Constituição Federal - o de receber serviço adequado, conforme definido no art. $6^{\circ}$ anterior.

Evidentemente, a enunciação de direitos, contida no dispositivo acima citado, comporta ampliação em regulamento ou em contrato.

Dentre eles, pinçamos, além do acima destacado, o direito de obter e utilizar o serviço com liberdade de escolha, observadas as normas do Poder Concedente, eis que está aí a matriz da possibilidade de eleição de fornecedor, conferida, pela legislação subsequiente, ao consumidor de energia elétrica, constituindo um dos alicerces da reestruturação do setor. Remarque-se, por oportuno, que essa ênfase na não exclusividade vem também expressa no art. 16 da Lei n ${ }^{\circ} 8.987$. 
Como calha a um diploma voltado para a disciplina da concessão de serviço público, por definição vocacionada para a satisfação do respectivo usuário, a Lei $\mathrm{n}^{\circ} 8.987$ trata em várias outras disposições, dos direitos e deveres dele, usuário, erigindo, inclusive, a cláusula que os regula em avença obrigatória do contrato de concessão (art. 23, inciso VI).

Vale, neste passo, lembrar, especialmente, a obrigação criada para o Poder Concedente, nos termos do art. 29, inciso XII, de

"estimular a formação de associações de usuários para defesa de interesses relativos aos serviços."

Embora, como vimos, a Lei ${ }^{\circ} 8.631$ já tenha previsto a instalação de Conselhos de Consumidores e a Lei ora abordada se ocupe de traçar' regras gerais, relativas aos direitos e deveres dos usuários, há muito o que se construir sobre essa matéria, no Brasil, nesse momento em que tanto se prestigia o instituto das concessões.

Seja porque a Lei ${ }^{\circ} 8.078 / 90$ foi concebida para a tutela dos interesses do usuário do serviço privado, contendo regras nem sempre compatíveis com os princípios da supremacia e indisponibilidade do interesse público, seja porque o avanço das concessões, no País, assim o requer, o fato é que hoje pretende-se instituir uma legislação que garanta a qualidade dos serviços públicos e a criação de uma estrutura de atendimento aos usuários. Nesse sentido, consoante noticiou a "Gazeta Mercantil", de 11.11.98, por iniciativa do Ministério da Administração Federal e Reforma do Estado MARE, foi elaborado Anteprojeto de Lei, voltado para a disciplina da "Participação e Defesa do Usuário do Serviço Público", posto para debate público.

Merece, ainda, realce o ter a Lei ${ }^{\circ} 8.987$ (arts. $2^{\circ}$, inciso II, 19 e 20) admitido a outorga de concessão a consórcio de empresas, o que vem suscitando questões de ordem jurídica, algumas delas abordadas em nosso artigo "Pontos Polêmicos da Legislação sobre Concessões e Permissões de Serviços Públicos" (RDA, vol. 205, págs. 70/72).

A análise dessas questões não se conforma aos limites traçados para o presente estudo, cujo objetivo é apontar os novos rumos do Direito da Eletricidade. Assim, para esse efeito, vem a propósito o mero registro da autorização legal para tal outorga, desdobrada, como veremos mais à frente, em outras disposições da recente legislação do setor.

Com a mesma preocupação, ocorre aludir à possibilidade de transferência da concessão, consoante norma insculpida no art. 27 da Lei ${ }^{\circ}$ 8.987. Dito permissivo tem, igualmente, despertado controvérsias doutrinárias, enfocadas no nosso trabalho supracitado. Aqui, porém, interessa-nos apenas dar-lhe destaque com o fito de apontar, adiante, seu entrelaçamento com regras contidas na posterior legislação específica.

De outra parte, sintonizado com a necessidade de se buscarem mecanismos mais modernos e ousados para o financiamento de projetos de infra-estrutura, o legislador introduziu na Lei a regra constante do art. 28 , pela qual os concessionários

“poderão oferecer em garantia os direitos emergentes da concessão, até o limite que não comprometa a operacionalização e continuidade da prestação do serviço." 
Percebe-se aí nítida tendência de dar um primeiro passo no sentido de facilitar soluções de financiamento, estruturadas sob a forma de project finance, definido por Walter Douglas Stuber ("O Financiamento de Projetos no Brasil e a Lei de Concessões", Max Limonad, 1996, pág. 19)

"como toda e qualquer modalidade de financiamento envolvendo obras de infra-estrutura elou prestação de serviços públicos, sob o regime de concessão ou permissão, em que seja possivel amortizar o financiamento com a própria receita gerada pelo projeto".

Essa alternativa representa uma ruptura em relação aos mecanismos tradicionais de financiamento, garantidos por meio de bens ou créditos da empresa patrocinadora do projeto de infra-estrutura. Aqui os financiadores contam com o fluxo de caixa do projeto como garantia, vale dizer, com o fluxo dos futuros pagamentos a serem efetuados pelos usuários dos serviços.

Por outro lado, na elaboração de um modelo de financiamento com essas características, a identificação de riscos desempenha papel crucial. Sem nos alongarmos no tema - que é vasto - podemos frisar que os diversos contratos envolvidos na sua montagem significarão notável redutor de riscos, na medida em que sejam claros e precisos.

É nesse contexto, muito rapidamente delineado, que se encaixa a regra do art. 28, acima referida, autorizando a previsão, no contrato de concessão, da possibilidade de cessão em garantia dos direitos emergentes da concessão - segundo os autores, receitas e os bens não discriminados como reversíveis - sem dúvida uma das medidas mitigadoras daqueles riscos, que vêm em auxílio da viabilização do project finance.

Teremos, na evolução deste estudo, oportunidade de verificar a repercussão da norma em apreço na legislação do setor.

Parece, outrossim, importante fazer menção aos arts. 29 e 30 da Lei em foco, nos quais estão elencados os encargos do Poder Concedente, merecendo relevo aqueles atinentes à regulamentação e fiscalização do serviço concedido, deferidos às agências, no caso do setor elétrico à já aludida Agência Nacional de Energia Elétrica - ANEEL, na forma da Lei ${ }^{\circ}{ }^{\circ}$ 9.427, de 26.12.96, que a instituiu.

Finalmente, impõe-se registrar que a Lei ${ }^{\circ} 8.987$, consoante o respectivo art. $42, \S 1^{\circ}$, ordenou a licitação das concessões, após o vencimento de seus prazos, e, segundo o seu art. $3^{\circ}$, extinguiu as concessões de serviço público, outorgadas sem licitação, na vigência da Constituição de 1988 , bem assim as outorgadas antes de sua promulgação, envolvendo obras não iniciadas ou paralisadas na data da edição da Lei. Na esteira dessa disposição, baixou-se, em 12.04.95, Decreto sem número, publicado no dia subsequiente, extinguindo as concessões de inúmeros aproveitamentos hidrelétricos.

No caso de obras atrasadas, previu a Lei que a extinção só operaria se, ao cabo de 180 (cento e oitenta) dias, as concessionárias não apresentassem um plano para sua conclusão. 
Como veremos, esses dispositivos foram modificados, em seguida, para concessões e autorizações de geração de energia elétrica.

\section{3 - A nova disciplina legal do setor elétrico}

a) Lei $n^{\circ} 9.074 / 95$

Se a Lei ${ }^{\circ} 8.987$, ao traçar normas gerais para a concessão de serviços públicos, lançou as bases para o redesenho do Direito da Eletricidade, encontra-se na Lei ${ }^{\circ}$ 9.074, de 07.07.95, um conjunto de regras que disciplinam matérias essenciais para a implantação da nova estrutura do setor de energia elétrica.

Tal Lei resulta do Projeto de Conversão da Medida Provisória n ${ }^{\circ} 890$, editada no mesmo dia da Lei $\mathrm{n}^{\circ} 8.987$, como forma de conciliar interesses para permitir a aprovação desta última pelo Congresso Nacional.

Como complemento da Lei ${ }^{\circ}{ }^{8}$ 8.987, a Lei em tela, além de encerrar disposições específicas, vinculadas ao setor acima referido, traz um ordenamento de cunho geral, do qual pode-se destacar a enunciação das atividades submetidas ao regime de concessão e permissão e as diretrizes para a reestruturação dos serviços públicos concedidos.

Mais uma vez, dirigiremos o foco de nossa análise da Lei, buscando, basicamente, estabelecer as relações entre as inovações nela encartadas e a revisão do setor elétrico, eis que a investigação, em maior profundidade, de cada um dos temas que tal estudo, com certeza, suscita não se mostra compatível nem com os propósitos nem com os limites deste trabalho.

O Capítulo II da Lei em exame enfeixa um conjunto de determinações dedicadas ao regramento dos serviços de energia elétrica, criando condições para a concretização de reformas, sintonizadas com as premissas estabelecidas para o novo arranjo do setor, como acima descrito.

Encontramos ali normas referentes ao prazo de duração das novas concessões de geração, distribuição e transmissão (limitado a trinta e cinco anos, no primeiro caso, e a trinta anos, nos outros dois) e de sua prorrogação (art. $4^{\circ}$ e respectivos parágrafos), à faculdade de cobrança, pela União, pelo uso de potencial hidráulico, à fixação de limites de potência de usinas hidrelétricas e térmicas, para efeito de submeter sua exploração à outorga de concessão, mediante prévia licitação, ou a mera autorização, e, já alterando a Lei ${ }^{\circ} 8.987$, à prorrogação das concessões então em vigor, alcançadas pelo art. 42 desta última.

Mas, ao lado dessas provisões de cunho mais geral, ocupou-se o legislador de introduzir regras vinculadas às premissas acima citadas, tais as relativas à figura do produtor independente de energia elétrica, ao livre acesso ao sistema de transmissão e à livre escolha, por parte dos grandes consumidores, de seu fornecedor de energia, quebrando, assim, o monopólio comercial das distribuidoras de energia.

Ao cuidar da geração de energia, a Lei se refere ao concessionário de serviço público, submetido ao regime da Lei Geral de Concessões, ao autoprodutor, titular 
de concessão de uso de bem público ou de autorização, conforme explore usina hidrelétrica ou termelétrica para uso exclusivo e ao produtor independente.

A figura do produtor independente foi criada com o objetivo de, a um só tempo, atrair investidores privados para a geração de energia, mercê de aplicarem-se às suas atividades regras mais flexíveis, e de propiciar a concorrência nesse segmento, ensejando-se ao consumidor optar pelo fornecedor que lhe ofereça preço e condições mais favoráveis.

Trata-se de um gerador que produzirá energia para seu consumo e para venda a terceiros, sujeitando-se a regras operacionais e comerciais próprias (art. 11).

De acordo com o art. $5^{\circ}$, inciso II, da Lei em comento, para o exercício de suas atividades, o produtor independente receberá uma concessão de uso de bem público, precedida de licitação, na hipótese de exploração de aproveitamento de potencial hidráulico de potência superior a $1.000 \mathrm{KW}$. Consoante o artigo subseqüente, se tratar de uma usina térmica, ficará a critério do Poder Concedente licitar a concessão ou dar uma autorização ao interessado.

O produtor independente pode fornecer energia aos consumidores livres, com perfil diferenciado, ou seja, consumidores de grande porte, conforme definido nos arts. 15 e 16 da Lei em foco, eliminando-se, quanto a estes, a exclusividade até então desfrutada pelas distribuidoras. Essa quebra de exclusividade, como vimos, fora autorizada pelos arts. $6^{\circ}$ e 16 da Lei $n^{\circ} 8.987$.

Prevê, ainda, a Lei a possibilidade do produtor independente vender energia a concessionário de serviço público ou, em condições excepcionais, enunciadas nos incisos IV e V do art. 12, a consumidores atendidos por concessionários. Nessas três hipóteses, estabelece o diploma legal em análise que os preços por ele praticados estarão "sujeitos aos critérios gerais fixados pelo poder concedente".

A idéia subjacente à criação dessa figura com regime jurídico específico - aliás, como vimos, uma das premissas do novo modelo - é a de que a geração de energia elétrica não deve ser considerada serviço público.

Embora ela tenha sido abraçada com entusiasmo pelo consultor escolhido para modelar a reestruturação do setor, a doutrina se divide quanto à sua admissibilidade, em face do disposto no art. 2I, inciso XII, letra b, da Constituição Federal, que trata os serviços de energia elétrica, indistintamente, como públicos, e no art. 175, da mesma Carta, que só autoriza a transferência de gestão a particulares de serviços assim qualificados através de concessão e permissão, segundo regime jurídico próprio.

Conquanto reconheçamos que o caminho mais adequado teria sido o de introduzir alterações na Constituição que legitimassem, sem sombra de dúvida, a existência desse gerador com as características almejadas, antes mesmo da regulamentação da Lei, abordamos o tema no artigo "Pontos Polêmicos da Legislação sobre Concessões e Permissões de Serviços Públicos", a que nos referimos acima, propondo uma interpretação que harmonizasse o texto legal e o constitucional.

Marçal Justen Filho ("Concessões de Serviços Públicos", Dialética, 1987, pág. 414) envereda pelo mesmo caminho, ainda que sob outro enfoque, quando preleciona: 


\section{"Parece-me viável, porém, adotar interpretação conforme a Constituição, que propicia inserção da figura no sistema jurídico.}

Somente se pode reconhecer sua constitucionalidade na medida em que se admita tratar-se de concessão. Não é possivel atribuir-lhe natureza própria e autônoma. Mas nada impede sua configuração como modalidade especial de concessão, com cunho complementar das concessões propriamente ditas".

Menciona esse autor (ob. cit., pág. 413) a opinião de Luiz Alberto Blanchet, no sentido de considerar inconstitucional a figura do produtor independente.

Entendimento diverso expressa Marcos Juruena Villela Souto ("Desestatização, Privatização, Concessões e Terceirizações", Lumen Juris, 1997, pág. 170), como se vê do texto adiante transcrito:

"Os serviços de energia elétrica compreendem três etapas, a saber, a geração, a transmissão e a distribuição; somente a segunda e a terceira etapas, que envolvem os sistemas e redes públicas e envolvem o consumidor (usuário), é que devem ser consideradas serviços públicos".

Diversos pontos podem ser trazidos à baila para aprofundar a reflexão sobre o tema, como, por exemplo, a conciliação entre o direito de propriedade de terceiros e a autorização, contida no art. 10, para o Poder Concedente declarar a utilidade pública de áreas necessárias à implantação de instalações de produtores independentes (e até de autoprodutores).

Todavia, para a ótica deste estudo, releva anotar a forma como a legislação procurou incorporar - decerto de modo canhestro - a premissa, adotada pelo Governo, de que a geração deveria ser tratada como indústria, ensejando o surgimento de múltiplos geradores e rompendo o monopólio dos distribuidores.

A esta altura, cabe elucidar que, para viabilizar a comercialização da energia produzida pelo produtor independente, a Lei tratou de, no respectivo art. $15, \S 6^{\circ}$, garantir o livre acesso aos sistemas de transmissão e de distribuição de concessionários e permissionários, mediante ressarcimento do custo do transporte envolvido. Com isto tem-se respaldo legal para mais um dos pressupostos da reforma em curso.

De outra parte, encontra-se no art. 17 e seus parágrafos a matriz da desagregação das atividades de geração, transmissão e distribuição, com a criação de uma rede básica dos sistemas elétricos interligados. Compõem essa rede as instalações existentes na data da Lei, como tal classificadas, e as futuras, a serem objeto de concessão, mediante licitação. No $\S 1^{\circ}$ da provisão em análise já se prevê a operação otimizada dessa rede, sob regras a serem definidas por "agente sob controle da União". Está aí o embrião do que seria o ONS.

Merece menção, ainda, a autorização contida no art. 18 subsequiente para a constituição de consórcio para geração de energia elétrica, voltado para a prestação de serviço público, para uso exclusivo dos consorciados, para produção independente ou para essas atividades associadas. 
O Decreto $\mathrm{n}^{\circ} 915$, de 06.09.93, já disciplinara essa matéria, tal era sua importância para permitir o concerto de parcerias com vista à retomada de obras paralisadas. Porém, apreciando representação que questionava a licitação para a formação de consórcio para a implantação e exploração da Usina Hidrelétrica de Itá, a Advocacia Geral da União, no Parecer GQ - 58, aprovado por despacho do Presidente da República, publicado no "Diário Oficial", do dia 21.02.95, entendeu que aquele diploma não oferecia suficiente sustentáculo normativo para tal, tendo desbordado os estreitos limites do sucinto art. 201 do Código de Águas, que regulamentava.

Voltando ao exame da Lei, mais adiante, verifica-se que o art. 20, modificando o parágrafo único do art. 43 da Lei $n^{\circ} 8.987$, permite a prorrogação das concessões e autorizações de geração de energia, com obras paralisadas, desde que se apresente plano para a respectiva conclusão, contemplando a participação da iniciativa privada com parcela superior a um terço dos investimentos a serem feitos.

Dita participação, segundo disposto no art. 21 , poderia ser selada mediante a constituição de consórcio, liderado pelo concessionário original, mantida ou não a destinação inicial da energia

Justamente para convalidar situações como a acima referida, envolvendo a parceria para a conclusão de Itá, é que, na forma do parágrafo único do artigo em tela, estendeu-se sua aplicabilidade a consórcios já formados ou em formação, na data da edição da Lei.

Tais regras, atinentes à constituição de consórcios, espancaram as dúvidas até então suscitadas, relativas à necessidade do concessionário de geração de energia quando se tratasse de empresa estatal - instaurar licitação para a escolha de seu (s) parceiro (s). Para implementação das parcerias, mostrou-se, outrossim, fundamental, além da autorização para transferência de concessões, constante, como vimos, do art. 27 da Lei $n^{\circ} 8.987$, a possibilidade de prorrogação das mesmas, admitida no art. 19 , eis que ao empreendedor privado deveria ser assegurado prazo tal que permitisse a amortização de seu investimento.

Além disso, essa possibilidade, conjugada com as normas inseridas no capítulo dedicado à reestruturação dos serviços concedidos, relativas ao deferimento à União de autorização para promover transformações societárias nas concessionárias sob seu controle, para aprovar cisões, fusões e transferências de concessões (art. 26, incisos I e II) e para a realização de leilão para outorga de nova concessão ou prorrogação das existentes, simultaneamente à privatização de empresas por ela controladas (art. 27), em articulação com o previsto no art. $8^{\circ}$ da Lei $\mathrm{n}^{\circ} 9.491$, criaram as condições para a venda imediata das distribuidoras de energia ESCELSA e LIGHT.

Diga-se, de passagem, que essa última regra, admitindo a possibilidade da adoção do leilão para outorga de concessão, provocou divergências doutrinárias, sobre as quais já nos posicionamos no nosso trabalho anteriormente aludido.

Em suma, a Lei $\mathrm{n}^{\circ} 9.074$, de um lado, fincou as raízes da profunda reforma, cuja concepção, àquela altura, ainda não adquirira nitidez, e, de outro, permitiu, com o conjunto de regras mínimas que encerrou, a adoção de providências mais imediatas, a exemplo das parcerias para retomada de obras, a licitação de concessões e as primeiras privatizações. 
Esses decretos regulamentam a Lei $\mathrm{n}^{\circ}$ 9.074. O primeiro deles, datado de 24.11.95, trouxe os procedimentos para prorrogação das concessões e enuncia o conceito de empreendimento de geração já iniciado, para os efeitos do art. 43, parágrafo único, da Lei $\mathrm{n}^{\circ} 8.987$, embora, curiosamente, várias concessões tenham sido canceladas por Decreto sem número, do mês de abril daquele ano, justamente por não terem sido encetadas as obras que demandavam. Vale dizer: o conceito que deveria informar a decisão só foi divulgado depois que a mesma havia sido adotada.

Já o Decreto $\mathrm{n}^{\circ} 2.003$, de 10.09.96, regulamenta a produção de energia elétrica por produtor independente e autoprodutor.

No seu art. $4^{\circ}$, o Decreto em tela define, regulamentando o art. $6^{\circ}$ da Lei ${ }^{\circ}$ 9.074, que a implantação de usina termelétrica, de potência igual ou superior a 5000 $\mathrm{KW}$, para exploração por autoprodutor ou produtor independente, ficará sujeita à obtenção de autorização do Poder Concedente. Para usinas, cuja potência fique abaixo daquele patamar, exige-se mera comunicação ao órgão fiscalizador.

Essa disposição regulamentar evoca questionamentos que imbricam com aqueles relativos à natureza do produtor independente, acima aludidos, eis que, se os serviços por este último prestados se configuram como serviços públicos, a inexistência de licitação importa em ofensa à norma inscrita no art. 175 da Carta Magna. Marçal Justen (ob. cit., pág. 417) sugere uma solução para o problema, assim sintetizada:

"Nas situações onde for impossível admitir-se número ilimitado de produtores independentes, terá de promover-se a licitação. Isso se passa quando o produtor independente pretende, por exemplo, utilizar-se de bem público para gerar energia... Já nas hipóteses de usinas termelétricas a situação é diversa. Não há limitações quanto ao número de usinas possiveis. Por isso, todo aquele que pretender a condição de produtor independente, quando se tratar de termeletricidade, poderá ser credenciado. Não haverá necessidade de licitação."

O Decreto em análise encerra as regras para a licitação de concessão a autoprodutor e a produtor independente, remetendo-se à Lei ${ }^{\circ} 8.987$, o que, mais uma vez, evidencia a ambigüidade da legislação no trato dessas figuras, já que, ao tempo em que determina que celebrarão contratos de uso de bem público - portanto, regidos pela Lei $\mathrm{n}^{\circ} 8.666$ submete - os ao regime da concessão de serviço público.

$\mathrm{Na}$ disciplina do assunto, traça normas relativas a consórcios, frisando que a concessão será compartilhada entre os consorciados, na proporção de sua participação, ficando a empresa líder responsável perante o Poder Concedente, sem prejuízo da responsabilidade solidária dos demais. Essa noção de compartilhamento de concessão também constitui uma novidade.

Estabelece, outrossim, que as concessões referentes a aproveitamentos de potenciais hidráulicos serão outorgadas a título oneroso, tornando agora mandatória, para estas hipóteses, a mera faculdade contida no $\S 1^{\circ}$ do art. $4^{\circ}$ da Lei $n^{\circ} 9.074$. 
O regulamento ocupou-se, ainda, de fixar em 35 (trinta e cinco) anos o prazo da concessão dada a produtor independente e a autoprodutor e de 30 (trinta) anos, o da autorização, prevendo a possibilidade de prorrogação. De outra parte, delineou o conteúdo básico do contrato de uso de bem público e da autorização.

Nos respectivos arts. 14 e 15, encontram-se disposições atinentes à modalidade de operação energética das centrais geradoras de autoprodutores e produtores independentes, deferindo-se competência ao Poder Concedente para, no contrato ou na autorização, conforme o caso, determinar ou não a operação integrada.

Dentre inúmeras outras regras, voltadas para a disciplina de encargos financeiros, fiscalização, penalidades, comercialização da energia produzida, cabe por em destaque aquelas referentes aos bens utilizados na produção de energia por autoprodutor e produtor independente.

Dispõe o art. 19 que tais bens, quando alocados a unidades de hidroeletricidade, bem como as linhas de transmissão associadas, não poderão ser removidos nem alienados, sem expressa aquiescência do órgão fiscalizador.

Mas, ampliando a autorização contida no art. 28 da Lei n ${ }^{\circ} 8.987$, antes abordada, permite que o financiamento para realização das obras ou serviços seja garantido não apenas pelos direitos emergentes da concessão ou da autorização - que identifica como sendo a energia elétrica a ser produzida e a receita decorrente dos contratos de compra e venda dessa energia, os chamados PPA - Power Purchase Agreement - como também com os bens empregados na produção de energia.

Admite, ademais, que, ficando inadimplente o autoprodutor ou produtor independente, como alternativa à declaração de caducidade da concessão ou à revogação da autorização, o Poder Concedente transfira o contrato ou a autorização a terceiro que preencha condições de qualificação. Ressalva, todavia, que a execução da garantia não poderá comprometer a continuidade da exploração da usina.

As regras acima citadas representam um passo significativo no sentido de facilitar os project finance. Por outro lado, delas transparece o dilema do legislador ao tentar conciliar a caracterização da produção de energia como mera atividade industrial e o amparo ao interesse público.

Ainda no que toca a esses bens, o Decreto soluciona a questão de seu destino ao final do prazo da concessão ou da autorização, prevendo, no caso de hidrelétricas, a respectiva incorporação ao Patrimônio da União, mediante indenização, e, em se tratando de usinas termelétricas, a respectiva remoção, sem direito a indenização.

Cumpre, finalmente, mencionar que o Decreto refere-se à possibilidade de encampação dos bens e instalações do autoprodutor e do produtor independente, por motivo de interesse público, bem como à caducidade da concessão ou revogação da autorização, tanto que verificada, em processo administrativo, a inadimplência daqueles, prevendo, nos dois casos, direito a indenização. A menção a essas duas modalidades de extinção do liame estabelecido com o Poder Público - típicas do contrato de concessão de serviço público - deixa, novamente, visíveis as contradições que as figuras do autoprodutor e do produtor independente, tal como postas na legislação, encerram, do ponto de vista jurídico. 
A Lei $n^{\circ} 9.427$, de 26.12.96, regulamentada pelo Decreto ${ }^{\circ} 2.335$, de 6/10/97, não obstante trazer em seu bojo algumas outras inovações na disciplina dos serviços de energia elétrica, teve por objetivo precípuo instituir a já aqui mencionada Agência Nacional de Energia Elétrica - ANEEL, que, por seu turno, foi criada para

"regular e fiscalizar a produção, transmissão, distribuição e comercialização de energia elétrica, em conformidade com as políticas e diretrizes do governo federal".

Essa entidade, à semelhança daquelas instituídas nos setores de telefonia e petróleo, nasceu da necessidade de o Poder Concedente controlar a prestação dos serviços públicos de energia elétrica, cuja gestão está sendo transferida à iniciativa privada. É que, conquanto encarregue-se o concessionário da execução dos serviços, a sua titularidade permanece com a Administração, que detém o poder de direção e controle dessa execução. Erigiu-se, portanto, como condição básica para a reestruturação do setor a criação de um órgão regulamentador independente.

Lê-se, por exemplo, no Relatório Gerencial, produzido, em 8.08.95, pela Comissão Interministerial de Desestatização do Sistema Eletrobrás, constituída para elaborar termos de referência para a contratação da modelagem do setor, por-se como um dos desafios para a implantação do redesenho do setor a

"reestruturação da função regulatória, contemplando inclusive os condicionantes para a delegação das funções do Estado e fortalecimento do novo "ente regulador" no exercício de suas funções, assegurando a sua atuação de forma independente, isenta e estável".

Mais adiante, já dando conta das reformas introduzidas no setor, o Ministério de Minas e Energia, no documento "Reestruturação e Desenvolvimento do Setor Elétrico Brasileiro - Encaminhamento e Resultados", de abril de 1998, arrola como a primeira das providências adotadas com o fito de promovê-las "a criação de um regulador independente e autônomo (ANEEL)".

$\mathrm{Na}$ construção do perfil institucional e da forma de atuação da agência, teve-se em vista a miríade de missões que lhe são atribuídas, tal como estabelecido nos arts. 29 e 30 da Lei $n^{\circ} 8.987$.

Assim é que, dentre as sua múltiplas atividades, destacam-se, em síntese, as seguintes: (a) regulamentar o serviço concedido e fiscalizar, permanentemente, a respectiva prestação, zelando por sua boa qualidade; (b) aplicar penalidades regulamentares e contratuais; (c) estimular a competitividade, o aumento da qualidade, da produtividade e da preservação do meio-ambiente; (d) incentivar a formação de associações de usuários para defesa dos interesses relativos ao serviço; (e) arbitrar os eventuais conflitos; ( $f$ ) celebrar contratos de concessão e de permissão de serviços de energia elétrica e de concessão de uso de bem público; ( $\mathrm{g}$ ) autorizar cisões, fusões e transferências de concessões; (h) celebrar convênios de cooperação com os Estados 
e o Distrito Federal, visando a descentralização das atividades que lhe competem; (i) declarar a utilidade pública dos bens necessários à execução do serviço ou instalação de energia elétrica.

Em suma, compete à agência conciliar os diversos interesses envolvidos na prestação dos serviços de que aqui se cuida, mormente o interesse público - aquele do conjunto de consumidores - e o interesse privado, precisamente o das empresas prestadoras do serviço.

Para bem desempenhar esse papel, seja em face da magnitude e relevância dos serviços públicos em tela, seja diante do poderio dos grupos nacionais e estrangeiros, que vêm assumindo a respectiva prestação, mostrou-se recomendável gozasse a agência - nos moldes do que se pratica no exterior - de independência, tanto em relação às empresas sujeitas à regulação e fiscalização, quanto ao Executivo e Legislativo, de forma a barrar a sua utilização para propósitos políticos.

Com vistas ao cumprimento dessa meta, foi a mesma constituída sob a forma de autarquia especial, vinculada ao Ministério de Minas e Energia, dotada de autonomia patrimonial, administrativa e financeira.

O Decreto-lei $\mathrm{n}^{\circ} 200 / 67$ define, em seu art. $5^{\circ}$, inciso I, a autarquia como

"o serviço autônomo, criado por lei, com personalidade jurídica, patrimônio e receita próprios para executar atividades típicas da Administração Pública, que requeiram, para seu melhor funcionamento, gestão administrativa e financeira descentralizada".

Concebidas para gozar de autonomia em relação às entidades estatais a que pertencem, que sobre elas exerceriam apenas controle finalístico, as autarquias foram-se desfigurando.

Assim é que, como assinala Eurico de Andrade Azevedo, no trabalho intitulado “Agências Reguladoras", publicado na RDA, n²13,

"o controle finalístico das autarquias (controle de resultados) foi sendo substituído pelo controle dos meios de sua atuação (admissão de funcionários, folha salarial, licitações etc.) resultando no engessamento de suas atividades, de tal sorte que pouco se distinguiam as autarquias de um departamento de administração direta."

Nesse contexto, surge, como alternativa, a criação da autarquia sob regime especial, enfeixando maiores privilégios do que aqueles atribuídos à autarquia comum, de modo a dotá-la da autonomia necessária à realização de sua vocação.

Destarte, ao desenhar a estrutura e atribuições da ANEEL, a Lei em comento e seu regulamento incorporaram regras que traduzem essas prerrogativas, tais, por exemplo, as relativas a critérios de escolha de diretores e respectivos mandatos e proteção quanto à sua remoção arbitrária do cargo e a financiamento próprio da agência, baseado em serviços prestados.

Vale aqui mencionar que a discussão em torno da extensão da independência das agências já chegou à Suprema Corte do País. 
De fato, o modelo importado de países como o Reino Unido, onde se admite sejam as agências realmente independentes do Governo, ficando suas decisões sujeitas apenas ao controle do Poder Judiciário, requer uma adaptação ao arcabouço jurídico brasileiro.

Assim é que, através da Ação Direta de Inconstitucionalidade ${ }^{\circ}$ 1.668-5, questiona-se, dentre inúmeros outros aspectos da Lei ${ }^{\circ}$ 9.472/97 (Lei Geral de Telecomunicações), a independência administrativa da Agência Nacional de Telecomunicações, mencionada no respectivo art. $8^{\circ}, \S 2^{\circ}$, dada a sua natureza autárquica, que pressupõe, na forma do art. 87, parágrafo único, da Carta Magna, a orientação, coordenação e supervisão do Ministro de Estado da área. Alega-se que a propalada independência administrativa importaria em ofensa à Constituição, eis que os entes administrativos autônomos hão de estar sempre subordinados ao controle de órgãos superiores da administração.

Ao apreciar o pedido de liminar, o Ministro Marco Aurélio, relator da referida ADIN, discorre sobre o tema, elucidando que

" a citada independência não afasta em si, o controle por parte da própria Administração Pública Federal, exercido, de forma direta, pelo Ministro de Estado da área e, de maneira indireta, pelo Chefe do Poder Executivo, o Presidente da República. Na verdade, o que encerra a alusão à citada independência é a autonomia, em si, do serviço, valendo notar que, de acordo com o art. $8^{\circ}$, a Agência Nacional de Telecomunicações está vinculada ao Ministério das Comunicações. Destarte, o enquadramento ocorrido, considerado o que se apontou como regime autárquico especial, longe está de revelar a existência de uma entidade soberana, afastada do controle pertinente." (Notas taquigráficas do Supremo Tribunal Federal)

Depreende-se do exposto, que, por recomendável e desejável que seja a independência da agência, o nosso sistema jurídico impõe-lhe limites.

Nesse diapasão, releva lembrar o disposto na Lei $\mathrm{n}^{\circ} 9.704$, de 17.11 .98 , no sentido de subordinar os órgãos jurídicos das autarquias federais à orientação normativa e à supervisão técnica do Advogado-Geral da União.

Essas considerações se aplicam integralmente à ANEEL, também ela revestindo a roupagem de autarquia especial.

No caso dessa agência, previu-se, no art. $7^{\circ}$ da Lei que a criou, que sua administração seria objeto de contrato de gestão entre a Diretoria e o Poder Executivo, constituindo este o instrumento de controle da atuação da autarquia e da avaliação de seu desempenho e, ainda, peça de auditoria contábil. A ANEEL deverá ficar sujeita, por conseguinte, a um controle finalístico.

A essa relativa, como vimos, autonomia administrativa da agência alinha-se a autonomia política, que decorre da forma de nomeação e exoneração de seus dirigentes, aquela de iniciativa do Presidente da República, mas subordinada à aprovação do Senado, essa necessariamente motivada, no bojo de processo administrativo, salvo nos quatro primeiros meses do mandato. Reforça-a a exigência de "quarentena", pelo prazo de doze meses, a contar do término do exercício do cargo. 
A autonomia financeira resulta, de seu turno, da cobrança aos concessionários, permissionários e autorizados da Taxa de Fiscalização de Serviços de Energia Elétrica, calculada sobre o beneficio econômico anual por eles auferido.

A natureza jurídica dessa taxa vem suscitando controvérsias. Marcos Juruena Villela Souto, em trabalho publicado na RDA n ${ }^{\circ} 216$, intitulado "Agências Reguladoras", registra a existência de duas correntes doutrinárias. Segundo a primeira delas, referida taxa revestiria a natureza de tributo, cujo fato gerador seria o exercício do poder de polícia, definido no art. 145, II, da Constituição Federal e no art. 78 do Código Tributário Nacional. O outro segmento da doutrina confere à citada taxa natureza contratual.

Após ponderar que, a prosperar o entendimento de que tal taxa reveste a natureza de tributo, sua previsão estaria vedada, eis que taxas não podem ter base de cálculo de imposto - o que, no caso, ocorre, já que a base consiste na receita apurada pelo concessionário, permissionário ou autorizado - o referido autor perfilha-se à segunda vertente, sob o argumento de que não se trata, na hipótese, de poder de polícia a ser custeado, mas de fiscalização do atendimento do interesse público, inerente à concessão.

Como remate das considerações aqui tecidas a respeito da independência da Agência, cabe mencionar que já se veiculou notícia ("Gazeta Mercantil" de 3 e 9 de março de 2000) de que a área econômica do Governo pretende restringir tal autonomia no que diz com a fixação de tarifas, mediante a introdução, em projeto de lei, da exigência de submissão ao seu crivo de revisões e reajustes tarifários. Ocorre sublinhar que dita iniciativa pode significar uma fissura na reforma que ainda se estrutura, em parte respaldada na rígida observância dos contratos de concessão.

Cabe, outrossim, por em relevo os arts. 20 e seguintes da Lei $n^{\circ} 9.427$, que permitem a descentralização, mediante a celebração de convênios de cooperação, das atividades complementares àquelas desenvolvidas pela Agência para os Estados e o Distrito Federal, matéria regulamentada pela Resolução $n^{\circ} 296$, de 11.09.98, da ANEEL.

A par de instituir a ANEEL, a Lei acima citada introduziu diversas novidades, das quais se destacam as seguintes: alteração das normas relativas à Reserva Global de Reversão - RGR, criada, como anteriormente referido, pela Lei $\mathrm{n}^{\circ} 5.655$, inclusive para determinar que do seu valor se deduza a acima citada taxa de fiscalização; modificação do art. $2^{\circ}$, II, da Lei $n^{\circ} 8.987$, de sorte a possibilitar a outorga de concessão para exploração de potenciais hidráulicos mediante leilão; previsão de que as concessões para a exploração de potenciais hidráulicos serão outorgadas a título oneroso, repisando e ampliando a regra do Decreto $n^{\circ} 2.003$, que tornou obrigatória a tímida faculdade contida na Lei $n^{\circ}$ 9.074; ampliação dos casos de outorga de simples autorização, pela agência, para exploração, por produtor independente, de potencial hidráulico, tornando-a possível, com alteração do art. $5^{\circ}$ da Lei $\mathrm{n}^{\circ} 9.074$, para potenciais de potência até dez mil KW; estabelecimento da primeira regra sobre importação e exportação de energia, subordinando o exercício dessa atividade, por produtor independente, bem como a implantação do sistema de transmissão a ela associado, à concessão de autorização pela agência. 
Se as leis antes citadas lançaram os fundamentos para a almejada reestruturação do setor elétrico, com a edição, em 27.05.98, da Lei $\mathrm{n}^{\circ} 9.648$, e, logo em seguida, em 2 de julho, do Decreto $n^{\circ} 2.655$, que a regulamentou, são introduzidas, no ordenamento jurídico pátrio, as regras que constituem os pilares dessa reforma.

Referido diploma, a par de trazer normas inéditas, necessárias à tarefa de estabelecer condições para o funcionamento do setor, com a nova feição que se lhe quer imprimir, alterou um conjunto de leis anteriores, algumas já examinadas neste trabalho, na maioria dos casos em pontos que interessam ao presente estudo.

Assim, por exemplo, modificou diversos dispositivos da Lei $n^{\circ}$ 8.666/93 (Lei de Licitações), cumprindo destacar, aqui, a criação de hipótese de dispensa de licitação, acrescentada, sob o inciso XXII, às previstas no respectivo art. 24, voltada para a

“contratação do fornecimento ou suprimento de energia elétrica com concessionário, permissionário ou autorizado, segundo as normas da legislação especifica".

A redação da regra peca pela falta de clareza. Inicialmente concebida para disciplinar a singela hipótese do distribuidor estatal que adquiria energia junto ao supridor (gerador de energia), também estatal, permite hoje interpretações que alargam bastante o objetivo inicial e que não foram ainda devidamente esmiuçadas pela doutrina. No limite, enseja o entendimento de que tais contratações poderão ser feitas sempre sem licitação. Também a Lei $n^{\circ} 8.987$ foi alterada pelo diploma em exame, valendo realçar a modificação do respectivo art. 15 para admitir novos critérios para o julgamento das licitações de concessões, introduzindo-se, no rol anterior, o de melhor proposta técnica, isolado ou combinado com aqueles já existentes.

\section{A Lei $n^{\circ} 9.648$ entronizou, ainda, novos ditames e alterações na Lei $n^{\circ} 9.074$.}

Nessa esteira, a norma insculpida no $\S 5^{\circ}$ do art. 15 contrabalança a possibilidade de livre escolha, por parte do grande consumidor, de seu supridor de energia com uma proteção aos demais consumidores da concessionária, no sentido de que isto não resultará em aumento tarifário, alterando, no particular, a regra anterior $\left(\S 7^{\circ}\right.$ do mesmo artigo).

Destaquem-se, outrossim, os relevantes acréscimos aportados ao art. 28 da Lei $\mathrm{n}^{\circ} 9.074$, que cuida da privatização de concessionárias estatais, seja para autorizar a modificação do regime de exploração para produção independente, seja para fixar regras voltadas para a proteção do uso da água das bacias hidrográficas e dos programas de desenvolvimento sócio-econômico regionais em áreas localizadas nessas bacias, onde se situam aproveitamentos de potenciais hidráulicos.

Mercê das dificuldades que já se apresentam com o início do funcionamento do modelo em implantação, mostraram-se também necessárias a inclusão de novos dispositivos e a introdução de alterações no texto da Lei $\mathrm{n}^{\circ} 9.427$. 
A preocupação com o estabelecimento de um mercado efetivamente competitivo demandou a inserção, no elenco de atribuições de competência da ANEEL, constante do art. $3^{\circ}$ do diploma reformado, a de determinar critérios e restrições para barrar os movimentos societários que levem à concentração econômica (veja-se, a propósito, a Resolução ANEEL $n^{\circ}$ 278/2000) e, ainda, a de zelar pelo cumprimento da legislação de defesa da concorrência, em atuação paralela à do Conselho Administrativo de Defesa Econômica - CADE, que tornará indispensável a articulação com a Secretaria de Direito Econômico do Ministério da Justiça, a que se refere o Parágrafo Único do dispositivo.

De outra parte, a ocorrência de falhas na prestação de serviços, por parte de empresas concessionárias, algumas delas já transferidas à iniciativa privada, apontou a omissão da legislação no que se referia à estipulação de multas a serem impostas, em face de tais eventos. Justamente para suprir essa lacuna, é que se introduziu, no art. $3^{\circ} \mathrm{em}$ tela, não apenas a autorização para a ANEEL aplicar a penalidade, como a determinação de critérios e teto para o respectivo cálculo.

Cabe, neste passo, dar especial relevo às inovações trazidas à redação do art. 26 da Lei $n^{\circ} 9.427$.

Ampliou-se, mais uma vez, no inciso I, a competência da ANEEL para conceder autorização para o aproveitamento de potencial hidráulico. Anteriormente - relembre-se - ela podia autorizar o aproveitamento de potenciais de potência superior a $1.000 \mathrm{KW}$ e igual ou inferior a $10.000 \mathrm{KW}$, destinados a produtor independente. Agora, cumpre-lhe autorizar o aproveitamento de potenciais com potência superior a $1.000 \mathrm{KW}$ e igual ou inferior a $30.000 \mathrm{KW}$, destinado à produção independente ou autoprodução, mantidas as características de pequena central hidrelétrica.

Há nesse dispositivo, bem como nas novas regras ínsitas aos $\S \S 1^{\circ}, 2^{\circ}, 4^{\circ}$ e $5^{\circ}$ do art. 26, um conjunto de condições concebidas com o fito de estimular o estabelecimento de pequenas centrais hidrelétricas ( $\mathrm{PCH}$ 's), cujas características estão definidas na Resolução ANEEL n ${ }^{\circ} 394 / 98$, às quais se reserva um importante papel no cenário de necessidade de criação de alternativas de suprimento de energia para o País.

Prosseguindo o exame do novo texto do art. 26, extrai-se da leitura do inciso II que o agente comercializador de energia - um daqueles múltiplos agentes, referidos no início deste estudo - dependerá de autorização para o exercício de sua atividade de compra e venda de energia. As condições para a obtenção da autorização são bastante singelas, como se infere do Parágrafo Único do art. $9^{\circ}$ do Decreto $\mathrm{n}^{\circ}$ 2.655 .

O texto do inciso III modifica o antigo inciso II do artigo em comento. Sob as novas regras, a importação e a exportação de energia continuam sujeitas a mera autorização da ANEEL, eliminando-se, todavia, a exigência anterior de que fossem feitas por produtor independente, ou seja, por proprietário de ativo de geração.

Finalmente, especifica-se, no inciso IV, que a comercialização do excedente do autoprodutor também depende de autorização da ANEEL.

$O$ art. $5^{\circ}$ da Lei $n^{\circ} 9.648$ cuida de traçar regras para a reestruturação da Centrais Elétricas Brasileiras S.A. - ELETROBRÁS e de suas subsidiárias, com vistas à respectiva privatização. 
Alvitra-se, no art. $7^{\circ}$ a possibilidade de, no âmbito dessa desestatização, alterar-se o regime de serviço público para produção independente. Vale observar que o Decreto $n^{\circ} 2.655$, em seu art. $5^{\circ}$, transforma esse "poder" em "dever", tornando a alteração imperativa.

Em sintonia com a norma inscrita no art. 24 da Lei ${ }^{\circ} 9.427$, estabelece-se que a nova concessão será outorgada a título oneroso, com a fixação do pagamento pelo uso do bem público, durante 5 (cinco) anos, em valor correspondente a até $2,5 \%$ da receita anual do concessionário. Tais recursos terão destinação idêntica à da RGR $\mathrm{e}$ serão administrados, de forma similar, pela ELETROBRÁS $\left(\S \S 2^{\circ} \mathrm{e} 3^{\circ}\right)$.

Prescreve o art. $8^{\circ}$ que a quota anual da Reserva Global de Reversão - RGR ficará extinta em dezembro de 2002, com a conseqüente revisão tarifária em beneficio dos consumidores.

$\mathrm{O}$ art. $9^{\circ}$ dá corpo à regra "ensaiada" no art. $15, \S 6^{\circ}$, da Lei $\mathrm{n}^{\circ} 9.074$, voltada para a materialização de uma das premissas básicas do novo desenho do setor: $a$ segregação, em contratos separados, ao contrário do regime em vigor sob a Lei $n^{\circ}$ 8.631, da compra e venda de energia e do livre acesso aos sistemas de transmissão $e$ distribuição de energia elétrica e do respectivo uso. Remete, para tanto, à ANEEL a regulamentação das tarifas e das condições de contratação do acesso àqueles sistemas e do seu uso.

De acordo com o art. $6^{\circ}, \S 2^{\circ}$, do Decreto $n^{\circ} 2.655$, as instalações e equipamentos que compõem a rede básica, de titularidade dos concessionários, são colocados à disposição do Operador Nacional do Sistema Elétricos (ONS), por intermédio do denominado "Contrato de Prestação de Serviços de Transmissão" (CPST), para coordenação e operação.

Há, aqui, envolvida uma questão de responsabilidade civil em caso de danos provocados por problemas ocorridos com essas instalações, eis que o concessionário está transferindo para o ONS a respectiva operação e este sequer possui patrimônio suficiente para respaldar eventuais indenizações. Essa fragilidade de estruturação jurídica, aliás, já veio à tona por ocasião do black out, ocorrido em março de 1999.

Além do CPST, a nova sistemática importa, ainda, na celebração, pelo usuário, do "Contrato de Uso do Sistema de Transmissão" (CUST), com o ONS, e do "Contrato de Conexão ao Sistema de Transmissão", com a concessionária.

As empresas concessionárias, proprietárias desses ativos de transmissão, farão jus a uma "receita anual permitida". As tarifas de uso e conexão também são reguladas pela ANEEL, tudo de acordo com a Resolução nº 142/99.

No art. 10 da Lei $n^{\circ} 9.648$ acha-se inscrita a norma que traduz o eixo central do novo arranjo setorial, vale dizer, a livre negociação para a compra e venda de energia.

Contudo, o mesmo dispositivo legal prevê um período de transição para o mercado livre. Nesse interregno, a compra e venda de energia, avençada sob os Contratos de Suprimento, previstos na Lei 8.631 , passa a constituir objeto dos chamados "Contratos Iniciais". 
Desse modo, para implementar o conceito de segregação de atividades, como deixa claro o art. 26, do Decreto-lei ${ }^{\circ} 2.655$, tem-se a substituição dos Contratos de Suprimento, ajustados sob a égide do art. $3^{\circ}$ da Lei ${ }^{\circ} 8.631$, por um conjunto de contratos, a saber: Contratos Iniciais, CPST, CUST e "Contratos de Conexão aos Sistemas de Transmissão".

Através dos "Contratos Iniciais", contratam-se, entre 1998 e 2002, os montantes de energia definidos no inciso I do art. 10 em exame. A partir de 2002, determina o inciso II subsequiente que os montantes a serem contratados sofrerão uma redução de $25 \%$ ao ano até que toda a energia fique disponível para a livre negociação.

Nessa fase intermediária, cumpre à ANEEL, na forma da Lei, regular as tarifas contempladas nos "Contratos Iniciais".

Constituem exceção ao princípio da livre negociação, na forma do $\S 3^{\circ}$ do artigo em análise, a energia proveniente da ITAIPU Binacional - porque disciplinada pela Lei ${ }^{\circ} 5.899-\mathrm{e}$ a energia termonuclear - que, por natureza, demanda regras próprias. Nessa linha, o art. 29 do Decreto $\mathrm{n}^{\circ} 2.655$ subordina à regulamentação específica, a ser baixada pelo poder concedente, o tratamento a ser dispensado a essa energia.

Já o art. 11 prevê a extinção gradual, nos sistemas interligados, até 2005, consoante condições e critérios ali traçados, da sistemática de rateio de ônus e vantagens, decorrentes do consumo de combustíveis fósseis para a geração de energia, a que se refere o inciso III do art. 13 da Lei ${ }^{\circ} 5.899$ (CCC). Remarque-se, todavia, que, segundo o $\S 3^{\circ}$, a CCC fica mantida por quinze anos nos sistemas isolados.

Estabelece o art. 12 subseqüente que as negociações de compra e venda de energia serão realizadas no âmbito do Mercado Atacadista de Energia Elétrica $M A E$, a ser instituído mediante "Acordo de Mercado", homologado pela ANEEL.

O MAE é o ambiente onde se realizam as supracitadas negociações, não sendo dotado de personalidade jurídica. Nesse forum, podem ocorrer transações do mercado de curto prazo (mercado spot) ou contratos bilaterais, com prazo definido. Trata-se de uma espécie de "bolsa de valores".

Do "Acordo de Mercado", firmado em 26.08.98, e chancelado pela ANEEL, nos termos da Resolução $n^{\circ}$ 018/99, participam os agentes envolvidos em atividades de comercialização (geradores, comercializadores, importadores e exportadores), observados critérios de volumes de negociação. Nele estão definidas as regras para seu funcionamento.

Sobreleva notar, dentre essas regras, aquelas voltadas para as garantias financeiras a serem, obrigatoriamente, oferecidas em respaldo das negociações no mercado de curto prazo.

Na estrutura do MAE prevê-se, como órgão deliberativo, a Assembléia Geral e, como órgão executivo, o Comitê Executivo - COEX.

Partindo-se da premissa de que "governance" é o processo através do qual decisões são tomadas, implementadas e cumpridas em uma organização, pode-se dizer que o MAE conta com um sistema de "governance", apoiado no COEX.

A necessidade de se aprovar a entrada em funcionamento do MAE, em setembro de 1998, determinou que isto ocorresse sem que, de um lado, os agentes estivessem 
seguros da preservação de seus direitos, o que os levou a apor ressalvas ao "Acordo", e, de outro, sem que regras fundamentais para a respectiva operação estivessem definidas.

Esse conjunto de incertezas e as características do sistema de "governance" do MAE, incompatíveis com um processo decisório ágil, têm dificultado o seu desempenho inicial.

Ainda a respeito do tema, deve-se mencionar que o novo mercado conta com suporte administrativo, oferecido pela Administradora de Serviços do MAE-ASMAE, constituída sob a forma de sociedade civil, pelos próprios membros do MAE.

No art. 13, situa-se a matriz legal para criação do já multicitado Operador Nacional do Sistema Elétrico - ONS, cuja instituição pôs-se sob dependência de autorização da ANEEL.

Houve modificação significativa em relação ao conceito enunciado no art. 17 da Lei $n^{\circ} 9.074$, ou seja, de um agente sob controle da União, eis que o ONS foi constituído como uma associação civil.

Dita entidade tem como membros agentes geradores, transmissores, importadores e exportadores, distribuidores e consumidores livres, e está autorizada, pela ANEEL, a executar a coordenação e controle da operação da geração e transmissão de energia elétrica nos sistemas interligados, visando a otimização desses últimos, através da Resolução n ${ }^{\circ} 351 / 98$.

O ONS conta, como fontes de receita, com as contribuições dos associados e com uma parcela dos encargos de uso do sistema de transmissão.

O objetivo mais importante, colimado com a criação do ONS, como anteriormente assinalado, consistiu na garantia de acesso, neutra e indiscriminada, à malha de distribuição.

\section{$V-$ Conclusão}

Como se pode perceber, a Lei ${ }^{\circ} 9.648$ veio arrematar o processo de construção do arcabouço jurídico básico, essencial à implantação do desenho concebido para o setor.

Pode-se, contudo, observar deste estudo que dito processo tem-se revelado extremamente dinâmico, requerendo constantes adaptações e complementações.

As Leis aqui mencionadas, como se demonstrou, foram bastante alteradas ao longo dos últimos anos e, a esta altura, já tramita no Congresso Nacional o Projeto de Lei $n^{\circ} 2.905$ que trará novas modificações.

A par disso, a ANEEL vem baixando um profusão de Resoluções para detalhar as determinações legais, de sorte a permitir a concretização do novo arranjo setorial.

Apesar das indefinições que têm marcado essa fase de transição, o quadro atual já permite vislumbrar a necessidade de novos ajustes no arcabouço legal.

Em primeiro lugar, há uma questão que vem sendo negligenciada, mas que, inevitavelmente, demandará providências no campo legal. Trata-se do possível aumento da carga tributária, em virtude do fracionamento das atividades do setor (desverticalização). Considerando que já existem novos custos, decorrentes de pagamentos das contribuições para o MAE e o ONS, das taxas de fiscalização à 
ANEEL, do uso de águas, todos eles repassados na tarifa, o aumento da carga tributária representará um ônus adicional para o consumidor.

Parece, pois, urgente o mapeamento da possível incidência de impostos para formulação de uma política tributária que contemple medidas mitigadoras.

Além disso, apesar de toda a reforma pela qual passou o setor, o risco de déficit de energia não está afastado, eis que não ocorreu, ainda, a expansão do suprimento nos níveis desejáveis.

O chamado "Plano Emergencial de Termelétricas" tem esbarrado em embaraços, alguns de ordem legal, que estão obstruindo o seu deslanchamento. Para viabilizar os project finance dessas usinas, faz-se imprescindível obter um PPA (Power Purchase Agreement). O principal desses óbices vincula-se a restrições legais a reajustes do preço da energia, que considerem a variação do dólar, moeda que se utiliza para a aquisição do gás a ser utilizado como combustível de tais plantas.

As condições de contorno desse obstáculo são sobremaneira complexas, eis que ameaçam a preservação de " dogmas" do Plano Real, e, até por isso mesmo, só podem emergir de alterações legais, que encontram forte resistência por parte da área econômica do Governo.

Para além desses aspectos, o cenário hoje visível legitima a antecipação de questões que surgirão em virtude da superposição de competências de agências como ANEEL e ANATEL, no caso, por exemplo, das infovias; da ANEEL e ANP, em controvérsias que envolvam negociações com gás; da ANEEL e CADE, na preservação da competição, o que decerto, demandará uma definição legal mais precisa das áreas de atuação de cada uma delas.

Ainda no âmbito do próprio setor elétrico, já começam a surgir questionamentos, concernentes à competência da ANEEL ou do MAE para dirimir controvérsias relativas à comercialização de energia. É possível que, aos poucos, seja necessário depurar, com maior clareza, na legislação, tais competências.

Em suma, neste passo, já se dispõe da moldura legal mínima, que deveria ter precedido a reestruturação do setor elétrico. Em face do atropelo que caracterizou dita reestruturação, a coerência e continuidade da infra-estrutura legal que a suporta ficaram bastante prejudicadas, como se buscou evidenciar, o que exigirá, no futuro, um trabalho de consolidação das mesmas.

De todo modo, para além dessa tarefa que já se impõe, tudo indica que, há, ainda, um longo percurso a ser trilhado, de forma a dotar o ordenamento jurídico de regras que respaldem, com segurança, o desenho proposto para o referido setor, propiciando o seu adequado funcionamento, a respectiva expansão, e, sobretudo, resguardando os interesses e direitos dos consumidores, que deve ser o alvo maior de toda a reforma concebida.

\section{Bibliografia}

DIREITO, Carlos Alberto Menezes. Reforma Administrativa: a Emenda $n^{\circ}$ 19/98. Revista de Direito Administrativo. Rio de Janeiro: Renovar, v. 213, 1998. PINHEIRO, Armando Castelar. O setor privado na infra-estrutura brasileira. Re- 
vista do BNDES. Rio de Janeiro, Banco Nacional de Desenvolvimento Econômico, v. 3, nº 5, 1996.

SEABRA FAGUNDES, Maria Aparecida de Almeida Pinto. Pontos polêmicos da legislação sobre concessões e permissões de serviços públicos. Revista de Direito Administrativo. Rio de Janeiro: Renovar, v. 205, 1996.

STUBER, Walter Douglas. O financiamento de projetos no Brasil e a Lei de Concessões. São Paulo: Editora Max Limonad, 1996.

JUSTEN FILHO, Marçal. Concessões de Serviços Públicos. São Paulo: Dialética, 1996.

VILlELA SOUTO, Marcos Juruena. Desestatização, Privatização, Concessões $\boldsymbol{e}$ Terceirizações. Rio de Janeiro: Editora Lumen Juris, 1997.

AZEVEDO, Eurico de Andrade. Agências Reguladoras. Revista de Direito Administrativo. Rio de Janeiro: Renovar, v. 213, 1998.

VILLELA SOUTO, Marcos Juruena. Agências Reguladoras. Revista de Direito Administrativo. Rio de Janeiro: Renovar, vol. 216, 1999. 


\section{Revista da Academia Brasileira de Letras Jurídicas}

Vários autores

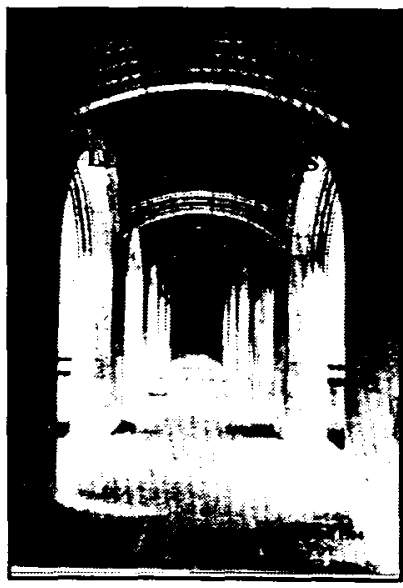

Um repositório de temas assinados por destacados mestres do Direito e cobrindo os mais diferentes ramos da Ciência Jurídica. O zelo editorial da Renovar assegura à Revista da Academia Brasileiras de Letras Jurídicas, uniformidade na apresentação, continuidade na publicação e amplitude na distribuição.

Ref. 0077

Brochura

Form. 14x21

\section{Revista da Faculdade de Direito da UERJ}

Coord. de: Wanda Vianna Direito e Elias Santana Gomes

A Revista da UERJ abriga a produção científica de mestres do Direito, com uma variada gama de especialidades jurídicas. Obra que se impōe para quem deseja estar atualizado com o que de mais moderno existe na literatura universitária.

Ref. 0086

Brochura

Form. 16x23

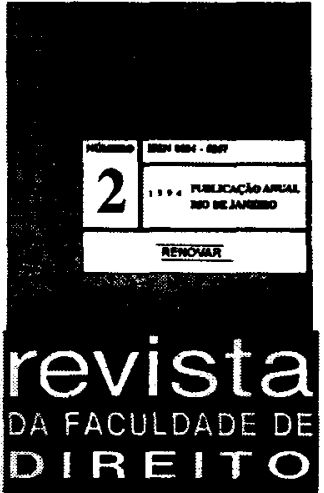

